\title{
Content analysis and exploratory factor analysis of relationship goals among young adults:converging data from instagram and offline surveys
}

\author{
Afifah Azizah and Juneman Abraham* \\ Psychology Department, Bina Nusantara University, Jakarta, Indonesia \\ Received: 28-September-2017; Revised: 04-December-2017; Accepted: 09-December-2017 \\ (C)2018 ACCENTS
}

\begin{abstract}
This psychoinformatical study aimed at finding out the growing aspirations on the relationship goals based on online and offline data. Three studies in an umbrella of social representation study were conducted involving 155 participants coming from Greater Jakarta and other Indonesia provinces (Study I, a preliminary study for extracting content frames on relationship; $M_{\text {age }}=21.6$ years), 610 samples of images captioned with \#RelationshipGoals in an online social media Instagram - originated mostly from Western users (Study II, a content analysis), as well as 367 participants coming from Greater Jakarta (Study III, a survey for Relationship Goals Scale construction; $M_{\text {age }}=22$ years). The results showed that there are three main dimensions of relationship goals, namely (1) Psychological Intimacy, (2) Sexual Activity, and (3) Religious Beliefs. It was found that religious belief should be the fourth pillar, not just the influencing factors of the Sternberg's triangular theory of love of romantic relationships. This study was successful in constructing relationship goals scale for the first time in Indonesia, to our best knowledge, which could be used for education and counselling. This present study also empirically indicated that the evolving analyses of Ulrich Beck, Stephanie Coontz, and Eli Finkel, that self-actualization has become the main romantic relationship goal, are perhaps exaggerated, especially in the context of social life of Indonesian. Individualized marriage might not be applicable as the representation of contemporary relationship zeitgeist in Indonesia. This study is pivotal in preventing marital divorce based on salient social meanings on the romantic relationship among young adults.
\end{abstract}

\section{Keywords}

Relationship goals, Theory of love, Relationship satisfaction, Social representation, Social network, Psychoinformatics.

\section{Introduction}

In the modern world of technology, various social media platforms and instant messaging applications have been created to facilitate communication among individuals. It has created a new method of communication in which users find ways to facilitate group discussion within a huge platform. In 2007, Chris Messina, a Twitter user, started the trend of using the symbol "\#” hashtag as a prefix preceding a word or phrase describing a certain topic of discussion such that Twitter users anywhere is able to access information related to the trending topic [1].

The use of the hashtag has traversed from Twitter to other social media platforms such as Facebook, Pinterest, and Instagram. Instagram has become one of the most frequently used media around the world and the second most leading form of social media platform in Indonesia.

*Author for correspondence
According to JakPat's research on the usage of the various different channels of social media, the results indicated Instagram has become the second leading form of social media platform in Indonesia [2]. Social media users age varies from $16-35$ in Indonesia $(N=1,033)$ in which at least $87.5 \%$ are active on Facebook, $69.2 \%$ are active on Instagram, $41.3 \%$ are active on Twitter, etc. The force that drove a high percentage of the use of the second most leading social media platform in Indonesia, Instagram, constitutes about $73.6 \%$ young adolescents ages 16$19,73.8 \%$ young adults ages $20-25,63.8 \%$ middle adults ages $26-29$ and $55.8 \%$ late adults ages 30-35 [2].

In relation to the use of hashtag, a common hashtag has been found on Instagram as a medium for sharing thoughts, emotions, and behavior through images\#RelationshipGoals have been commonly found within captions of couple-images in which there are at least 5,554,651 posts embedding this hashtag and is increasing by the minute. Based on 
KnowYourMeme, \#RelationshipGoals is a common hashtag used within the caption of the images which exhibits a worthy type of romantic relationship to be achieved with a significant other [3]-it's a content that signifies everything one desires to be romantically [4]. In addition, Relationship Goals became a popular language in a couple-images posted on social media, however, the hashtag's original birth is still unclear [3]. Nevertheless, articles regarding Relationship Goals have smeared over the internet since June 15th, 2009 starting off with a post by Lifehack.org related to "Relationship Goals: 8 Traveling Couples to Follow on Instagram" [4]. The article consisted of 8 couples who have gone out of their conventional lifestyle and submerged into a digital nomadic lifestyle filled with travel experiences.

In the eye of the perceiver, each of these images has its own categorization and conveys a different story. After the hashtag's inception in 2014, articles related to relationship goals have been widely spread across the internet, each conveying a polar point of view. It conveyed a positive point of view on how these couples choose an alternative lifestyle from their already successful, conventional one by traveling together to see the world [4]. At a glance, without a further interview with these couples, no one would know the story behind these images. However, partners have made posts with a significant other as a means of showing their love [5]. These images portray the magnified, filtered, luxurious, aesthetic aspect of their travels - rather than the trouble they faced during baggage check/claim, immigration check, or even security check. The portrayal of aesthetic perfection brings about a need in an individual to have, expected or experience the same things in their lives - one of the 4 categories of needs that Maslow (as cited in [6]) theorized.

These images may portray the real world for those who post them - however, such images can be out of reach for the individuals who see them. Aesthetic couple-images do not only apply to traveling couples, but also to public figures people see on Cosmopolitans or Entertainment News [7]. \#RelationshipGoals have also been associated with the portrayal of celebrities' relationships [3], 7]. During the divorce of Brangelinas (Brad Pitt and Angelina Jolie), viewers became so wrapped up in the lives of celebrities such that when a falling out occurs between the couple, the impact is felt in real life. Sentiments such as "How can I ever believe in Love anymore?" or "Love is dead" or "Why Should I ever become attached to another celebrity couple ever again?" have floated around on Twitter for days [7]. Fans do not even know their celebrities, probably have never even met them in real life before, however, their lives somehow affect how individuals view relationship - it is startling and also terrifying.

Aesthetic couple-images are a fabrication of another individual's life story, one that should not be internalized by an individual. In an opposing article, an interview with a psychologist specializing in marriage and family, Esther Boykin stated that the couple-images with \#relationshipgoals do not convey a real happy, long-lasting relationship [8]. These images portrayed such as kissing of a cliff, proposals with Broadway productions, his-and-hers matching Bugattis are not indicators of true love [8] - a fantasy that is outlived as an essential need for perfection in life. It's human nature to always compare what one has with that of the others - there is a proverb "The neighbor's grass always looks greener"-an indication that one tends to compare oneself to other people; a behavior that can have detrimental effects on relationship outcomes [9].

Nevertheless, there is a lack of studies regarding the hashtag itself to make a connection between the portrayed couple images and the impact on the individual's own romantic relationship. Among married individuals, goals play an important role in maintaining marital stability and quality which eventually leads to marital satisfaction [10]. It serves as one of the ingredients required to avoid conflict and maintain a harmonious relationship, such that it does not end in divorce $[11,12]$. As the divorce rate has been found to increase from 2014 to 2015 based on the amount of the increase in divorce cases filed to Indonesian Directorate General of Religious Court System Bodies [13], it brings about researcher's curiosity as to what aspects of goals are found among young adults and the represented goals in \#RelationshipGoals Imagery.

As hashtag, specifically \#RelationshipGoals, have become a digital phenomenon that withholds various information regarding the romantic relationship, the researcher is keen to understand the newly embedded phenomenon within our society. According to Social Representation Theory introduced by Moscovici (as cited in $[14,15])$, social representation refers to widely held ideas and values which include assumptions and cultural ideologies between groups of individuals-it helps people make sense of the world that they live in. Constantly, humans are 
bombarded with unfamiliar and novel phenomenon within their social world; it is bound to happen that daily interactions create a unified representation of objects within their surroundings. The dynamics of group interaction to creates a consensus towards unfamiliar objects or events (e.g. phenomenon) which in turn creates a new form of knowledge and construed social entities termed as social representative [16].

Social representation theory (SRT) serves as a social psychological framework filled with concepts and ideas that can be used to study psychosocial phenomena within modern societies [17]. It is a model that explains how a belief system is formed through the fundamental process of interpersonal communication as a determinant factor, forming a concept in which most social psychologists term as social representation [18]. In summary, the conceptual definition of social representation refers to an ensemble of thoughts and feelings expressed through verbal and overt behaviors of individuals within a society regarding a social object in their surroundings [17].

Those objects or phenomena can be of various forms [16] such as physical (e.g. bathroom), interpersonal (e.g. friendship), mythological (e.g. "Buto Ijo" or "Green Giant" in Javanese myth) or socio-political (e.g. Liberals) - events or objects that occur within one's society can become an object of social representation in which content and meaning can be embedded within them. In accordance with this theory, it indicates that an object becomes a society's representation through the way people relate to it by attributing features and meanings towards the object making it a group shared conception [17].

It is to say that individuals exhibit action regarding a certain phenomenon where members of the same group or opposite groups create an understanding and co-construct meaning towards the phenomenon. People's overt reactions, either in the form of verbal or physical actions, serve as a frame in which they are able to understand how the relationship between the objects and subjects (i.e. The people themselves) is defined [17]. By employing SRT as a method, the researcher seeks to understand how relationship goals have been socially represented. In accordance with Figure 1, the cycle of a new social representation being formed starts off from how a new phenomenon is introduced followed by a process of discourse through which individuals perform a process called anchoring by using a familiar and known term towards the new phenomenon. This is achieved by conducting a study in which researcher is able to obtain a framework for identifying the most salient aspects of goals within romantic relationship found among young adults in Indonesia. Afterwards, this framework would be used to identify the aspects of goals in \#RelationshipGoals Imagery-a process within the cycle known as objectification; a method of assigning symbols or images to the newly represented term. The result of the represented social term of relationship goal found on social media platform can be used to find aspects of goals within a romantic relationship among young adults, in general. With this, as a means of finding out what aspects of goals within romantic relationship goals are present among young adults, the researcher would conduct numerous studies to obtain descriptive information regarding relationship goals.

In relation to the elaborated phenomenon and how relationship goals can be studied through the use of social representation theory, the researcher conducted 3 separate studies as a means of answering the following research questions: (1) What are the desired goals in the romantic relationships among young adults in Indonesia?; (2) What content frames and descriptive information regarding the content frames are commonly found among images and caption on Instagram with \#RelationshipGoals?; and (3) What are the factors of relationship goals?

\section{Materials and methods}

As a means of finding answers to the previously stated questions, the researcher had to identify the type of research design to be employed, participants to be studied, sampling technique to be used and what instrument of measurement to be administered. As there are 3 research questions, each would be explained by a study of their own which are interrelated through the social representation method.

\subsection{Design}

Within this study, the researcher has employed a qualitative approach to obtain data based on the questions that have been formulated. However, with this approach, in each study, qualitative and quantitative data can be obtained. Specifically, the researcher employed a descriptive research strategy as a means of studying the variable as it really exists within the environment without any prior assumptions [19].

Within Study I-Preliminary Study, as a means of creating an anchor to which researcher is trying to 
understand the concept of relationship goals, a descriptive research design is best to be employed in order to find out aspects of goals within a romantic relationship possessed by younger adults. By creating open-ended questions related to personal goals, undesired goals, and desired goals, the researcher is able to obtain content frames describing goals within a romantic relationship.

Within Study II-Content Analysis, as a means of creating an objectified symbol of the term relationship goals, through the phenomenon of hashtags and the spread of couple-images between Instagram users, the term relationship goals have been linked to couple-images, relationship-images, etc. on Instagram that includes the caption \#RelationshipGoals. With this, the researcher employed content analysis as a means of identifying aspects of goals within these images based on young adult's responses to open-ended questions related to goals within a romantic relationship. As the participants within Study II involved images and caption, content analysis best fits the method of approach as it serves to analyze the content of various mediums such as images, video, literature, etc. [19, 20]. It will involve the use of inter-rater as a means to identify the existence of the content frames in each of the images and captions.

Within Study III-Exploratory Factor Analysis, as there is a new social representation of the term relationship goals among Instagram users, the aspects of goals within a romantic relationship is tested towards general young adults by creating a new scale (Relationship Goal Scale) that includes content frames found in Study I and Study II. Study III serves as an additional and further analysis of the newly represented social terms; relationship goals. Exploratory factor analysis is the best method to be employed as to identify the existence of the content frames among young adults in a reduced number of variables [21].

\subsection{Participants}

\subsubsection{Study I-preliminary study}

Researcher aimed to obtain information related to the goals within a romantic relationship possessed by young adults. The target participants are individuals within their early adulthood (ages 20-35) [22], who either had or have not had a romantic relationship experience and can either currently be or currently not be in a romantic relationship. As researcher does not know the specific amount of young adults' population with these specific characteristics, a non- probability sampling technique is employed [19]. Specifically, the researcher employed snowball sampling technique as a means of obtaining a chain of referrals to help spread out, identify, choose and obtain data from the targeted participants [23]. In addition, researcher utilized thematic analysis as a means of categorizing similar responses from the open-ended questions and coded them into one single content frame. The thematic analysis serves as a data analysis technique in which data pooled is structurally organized in terms of frequency and classified based on similarities in the pattern [24].

2.2.2Study II-content analysis

The targeted participants are images along with its captions on Instagram with \#RelationshipGoals. As a means of objectifying the term relationship goals, researcher related the responses on Study I to Study II. The criteria of images along with its captions are as such: (1) individuals who post these images are within their early adulthood; ages 20-40 years old, (2) individuals who post these images can currently not be in a romantic relationship and can either have had or have not had a romantic relationship experience and (3) individuals who post these images should have no indication that they are married or have any children. As the probability of obtaining the kind of images along with its captions (e.g. coupleimages, scenery, memes, quotes, etc.) is unknown, researchers employed quota sampling as a means of obtaining the number of images and caption to be analyzed based on a content analysis study conducted by Tiggemann and Zaccardo [25] on \#fitspiration imagery on Instagram. With this, the researcher obtained 610 images and captions with \#RelationshipGoals.

Furthermore, as content analysis employs the use of inter-raters, the characteristics of participants resemble that of Study II where participants should be (1) in their early adulthood within the age range of 20-35 years and (2) individuals who are currently or not currently in a romantic relationship. As for the inter-raters, researcher specifically employed convenience sampling by selecting the most easily available participants by personally asking individuals with the specified criteria.

2.2.3Study III-exploratory factor analysis The criteria for participants resemble that of Study II. Researcher specifically aims to obtain responses from (1) individuals who are in their early adulthood, ages 20-35, (2) individuals can either currently be or not be in a romantic relationship and can either have had or have not had a romantic relationship experience. As researcher constructed a new scale (Relationship 
Goals Scale/RGS) of measurement, quota sampling technique would be employed to ensure the number of individuals needed within the subgroup [19]. Within the construction of measuring instruments, data collected to ensure a valid response is based on the number of variables or items created [26]. It is recommended that item-to-response ratio ranges from 1:4 to at least 1:10 (Rummel, Schwab, as cited in [26]). With this, researcher applied a ratio of 1:5, thus, requiring a total of 335 participants based on 67 elicited items. The RGS was spread through an online form using the Google form.

\subsection{Materials}

\subsubsection{Study I-preliminary study}

The researcher employed open-ended questions obtained from several journals related to the relationship goals (e.g. [10]), and personal goals (e.g. [27]) as a means of obtaining information regarding the most salient goals possessed by young adults. The adaptation was made to the instruments such that the question was translated from English to Indonesian and face validity was performed to ensure that it fits into the cultural context.

\section{In English}

"Please think carefully about certain desired goals or end-states in your relationship that you would want to come true. It does not matter if such things have occurred or not. Imagine positive things such as having the opportunity for mutual self-disclosure or making your partner feel like a worthy person. Desirable traits of your partner or your own personal goals, such as your careers, are not important in the present context. Please provide 5 desired goals".

\section{In Indonesian}

"Pikirkan dengan baik-baik mengenai beberapa tujuan atau hasil akhir yang Anda inginkan menjadi kenyataan DALAM HUBUNGAN ROMANTIS ANDA! Tidak masalah jika hal tersebut sudah ataupun belum terjadi. Bayangkan hal positif seperti memiliki kesempatan untuk saling mengungkapkan diri atau membuat pasangan merasa seperti orang yang berharga. Sifat yang diinginkan dari pasangan Anda ataupun tujuan pribadi Anda, seperti karir yang baik, bukan menjadi hal yang penting dalam konteks ini! Berdasarkan renungan Anda, sebutkan 5 atau lebih TUJUAN yang diinginkan dalam hubungan romantis Anda!"

Furthermore, questions regarding the participant's general goals were also asked and were obtained from the study conducted by Ranta, Dietrich, and
Salmela-Aro [27]-it serves as an additional question to gain more insight into the most salient goals the individual possesses.

\section{In English}

"People have many kinds of issues and goals they think about, hope for, and try to accomplish. Consider the personal projects you have in your life at the moment. These projects may be related to any life domain, such as education, work, family, or selfrelated issues."

\section{In Indonesian}

"Pada umumnya, manusia memiliki banyak jenis permasalahan dan tujuan yang mereka pikirkan, harapkan dan coba untuk mencapai. Pertimbangkan tujuan pribadi yang Anda miliki dalam hidup saat ini! Tujuan-tujuan tersebut mungkin terkait dengan domain kehidupan, seperti pendidikan, pekerjaan, keluarga atau masalah yang berkaitan dengan diri sendiri. Berikan 4 atau lebih tujuan pribadi yang Anda miliki!"

In addition, the researcher also assessed individual's awareness regarding the hashtag \#RelationshipGoals "Seberapa sadarkah Anda mengenai hashtag \#RelationshipGoals yang beredar dalam caption foto-foto di Instagram?" (How aware are you about the hashtag \#RelationshipGoals that circulated in photo captions in Instagram?) in which the scale response was obtained from a study conducted by Abdullah, Ismail, and Murad [28], the time they spent on Instagram and their opinions regarding the significance of images with \#RelationshipGoals as a means of obtaining a more in-depth information regarding the phenomenon at hand.

2.3.2Study II-content analysis

In order to obtain the most the most salient types of goals embedded within images and captions with \#RelationshipGoals, the researcher used the responses in Study I to obtain content frames related to aspects of goals within romantic relationships. As content analysis requires a coding process in which inter-raters verify the reliability of the formed content frames in Study $I$ [20, 23], researcher created a coding book in which inter-raters can use to verify the existence of content frames by putting an (X) on the column of choices -4 inter-raters were used. The coding book was created based on a study that has been conducted by Woychick [29] related to the analysis of international student's identity through the images they post on Instagram. Within the coding book, researcher provided instructions on how to carry out the coding process, what aspects to look at 
(i.e. images and caption) and the operationalized definition of 12 content frames formed from Study I. 2.3.3Study III-exploratory factor analysis

Researcher created a new scale (i.e. Relationship Goal Scale) that have been based on the result of content analysis (see Table 1). The scale was constructed based on the agreement among 4 interraters for 610 images that they have analyzed. For each content frames, there are images in which 4 inter-raters agree to have that aspect of goals embedded within the imagery. From the commonalities found, researcher elicited items conveying the content of the image in reference to the content frame. At least 5 items have been created for each content frame. The scale was constructed on a 6-point Likert Scale ranging from Strongly Disagree (scored 1) to Strongly Agree (scored 6).

\subsection{Reliability}

2.4.1Inter-rater reliability

In order to be able to obtain an accurate, comprehensible measure regarding the unit elements or content frames elicited through the process of content analysis, it is necessary to conduct reliability measurement. Reliability refers to the degree in which the instruments elicit a similar response throughout time [19]. Within this study, the researcher would conduct a form of reliability testing known as inter-rater / inter-coder reliability, among 4 raters, in which the aim is to obtain a quantified degree of agreement between observers as they, simultaneously and independently, examine the images in accordance with the specified coding rules. The result is able to demonstrate consistency in observational ratings provided by multiple coders.

Based on the result of 4 inter-raters, through analysis using SPSS vs 20, it can be concluded that within Take and Give content frame, there are 2 nonsignificant models and 4 significant models with Kappa value less than .400 indicating a poor agreement [20]. Nevertheless, these models exhibit some valid level of agreement among the images in NO responses, which indicates an existence of the content frame throughout 610 images. Within Acceptance and Cogitation content frames, all interrater results exhibit significant models with 3 models having Kappa value greater than .400 which indicates a fair to good agreement and 3 models having Kappa value less than .400 which indicates a poor agreement. Nevertheless, these 3 models with Kappa value less than .400 reveals some valid level of agreement among the images in NO responses, which indicates an existence of the content frame throughout 610 images.

Meanwhile, in Co-joint Activity and Sexual Activity content frames, all inter-rater results exhibit significant model with all models having Kappa value greater than .400 , which indicates a fair to good agreement. Within Commitment content frames, all results exhibit significant models with 2 models having Kappa value greater than .400 and 4 models having Kappa value less than .400. Even though these 4 models have a poor agreement, they reveal some valid level of agreement among NO responses, which indicates an existence of the content frames throughout 610 images.

Furthermore, within Self-exploration, Relationship Development, Value and Brings Positive Impact content frames, all inter-rater results exhibit significant model, however, Kappa value is less than .400. Nevertheless, these 6 models exhibit some valid level of agreement among the images in YES and NO responses indicating an existence of the content frame throughout 610 images. As for Teamwork and Participant Characteristics, all inter-rater results exhibit significant model with 1 model having Kappa value greater than .400 and 4 models having Kappa value less than .400. Nevertheless, these models exhibit some valid level of agreement among YES and NO responses, indicating an existence of the content frame throughout 610 images. The researcher concludes that these 12 content frames are present within 610 images that inter-raters have rated on. 2.4.2Relationship goal scale validity and reliability As for Relationship Goals Scale (RGS), the researcher would conduct validity and reliability testing. Validity refers to refers to the extent in which the instruments measure what is intended to be measured [20]. The researcher performs face validity regarding the elicited items for 12 content frames. Face validity is the simplest form of validity assessment where targeted participants are asked to give their opinions about the superficial appearance of the instruments (i.e. elicited items). The aim of face validity is to assess whether the instruments measure what is claimed to be measured at face value.

Meanwhile, reliability refers to the degree in which the instruments elicit a similar response throughout time [20]-it is conducted after the factors have been formed (i.e. Exploratory Factor Analysis). 
Table 1 Blueprint of relationship goals scale

\begin{tabular}{|c|c|c|c|c|}
\hline No & Dimension & Indicators & Item no & Total \\
\hline 1. & Take and Give & $\begin{array}{l}\text { Describes mutual behavior that is exhibited by each partner within the } \\
\text { relationship. Each partner would receive and give something for one } \\
\text { another. }\end{array}$ & $\begin{array}{l}1,4, \quad 7, \\
10,13\end{array}$ & \\
\hline 2. & $\begin{array}{l}\text { Acceptance by } \\
\text { partner, family } \\
\text { and social circle }\end{array}$ & $\begin{array}{l}\text { Describes an individual's desire to be accepted within the life and } \\
\text { surrounding environment of his/her partner. It is depicted by an } \\
\text { individual's closeness with partner's family, his/her effort to be liked by } \\
\text { the family and / or his/her effort to get to know the family. }\end{array}$ & $\begin{array}{ll}50, & 54, \\
57, & 60, \\
63 & \end{array}$ & 5 \\
\hline 3. & Co-joint Activity & $\begin{array}{l}\text { Activities that are carried out simultaneously. These activities are } \\
\text { diverse, it can start from spending time together such as going to the } \\
\text { movies or having date nights to doing hobbies together. }\end{array}$ & $\begin{array}{ll}3,6,9 \\
12, & 15\end{array}$ & \\
\hline 4. & Commitment & $\begin{array}{l}\text { An individual's desire to take more serious responsibility in his/her } \\
\text { relationship with partner. It can be depicted through behaviors such as } \\
\text { proposing, getting engaged, getting married, building a family together, } \\
\text { etc. }\end{array}$ & $\begin{array}{ll}16, & 19, \\
22, & 25, \\
28 & \end{array}$ & 5 \\
\hline 5. & Self-exploration & $\begin{array}{l}\text { Describes an individual's desire to be able to understand him/herself in } \\
\text { depth, to know new things about him/herself, to be authentic and be able } \\
\text { to express who he/she is within the relationship }\end{array}$ & $\begin{array}{ll}17, & 20, \\
23, & 26, \\
29 & \end{array}$ & 5 \\
\hline 6. & $\begin{array}{l}\text { Relationship } \\
\text { Development }\end{array}$ & $\begin{array}{l}\text { An individual's desire for the relationship to progress towards a more } \\
\text { serious phase. Relationship develops towards more than just dating, but } \\
\text { it can transform into companionship, becoming fiancés, marriage, } \\
\text { kinship, etc. }\end{array}$ & $\begin{array}{l}18 \\
24 \\
30\end{array}$ & 5 \\
\hline 7. & Teamwork & $\begin{array}{l}\text { Partners work together to achieve common goals by communicating } \\
\text { well, solving problems together, setting common goals, synchronizing } \\
\text { thoughts, etc. }\end{array}$ & $\begin{array}{ll}31, & 34, \\
37, & 40, \\
43 & \end{array}$ & 5 \\
\hline 8. & $\begin{array}{l}\text { Partner's } \\
\text { Characteristic }\end{array}$ & Traits and characteristics desired by an individual in his/her partner. & $\begin{array}{l}32, \quad 35 \\
38, \quad 41 \\
44,46\end{array}$ & 6 \\
\hline 9. & Value & $\begin{array}{l}\text { Beliefs held by one partner and / or both partners in a romantic } \\
\text { relationship. }\end{array}$ & $\begin{array}{ll}33, & 36, \\
39, & 42, \\
45, & 47, \\
51, & 55, \\
58, & 61, \\
64 & \\
\end{array}$ & 11 \\
\hline 10. & Cogitation & $\begin{array}{l}\text { Small or big gestures carried out by an individual for his/her partner. It } \\
\text { can be depicted through anniversary celebrations, surprises that are } \\
\text { memorable for other people, each partner and / or their surrounding } \\
\text { environment. }\end{array}$ & $\begin{array}{ll}48, & 52, \\
56, & 59, \\
62 & \end{array}$ & 5 \\
\hline 11. & $\begin{array}{l}\text { Brings } \quad \text { Positive } \\
\text { Impact }\end{array}$ & $\begin{array}{l}\text { Positive things that result from a relationship with an individual. Positive } \\
\text { things can have an impact on other people, each partner and / or their } \\
\text { surrounding environment. }\end{array}$ & $\begin{array}{ll}49, & 53, \\
65, & 66, \\
67 & \end{array}$ & 5 \\
\hline 12. & Sexual Activity & $\begin{array}{l}\text { Individual's need to be physically connected with their partner. It can be } \\
\text { depicted through behaviors such as holding hands, kissing, hugging to } \\
\text { having sexual intercourse etc. }\end{array}$ & $\begin{array}{l}2,5,8, \\
11,14\end{array}$ & \\
\hline \multicolumn{3}{|c|}{ Total of Items } & 67 & 67 \\
\hline
\end{tabular}

Table 2 Internal consistency of relationship goals scale

\begin{tabular}{lllllll}
\hline Factor & Item & Deleted Items & Final Item & Cronbach's Alpha & CIT $^{*}$ min & CIT $^{*}$ max \\
\hline Factor 1 & 34 & 0 & 34 & 0.966 & 0.492 & 0.845 \\
Factor 2 & 5 & 0 & 5 & 0.809 & 0.497 & 0.763 \\
Factor 3 & 6 & 0 & 6 & 0.847 & 0.444 & 0.781 \\
\hline
\end{tabular}

Note. ${ }^{*}$ CIT $=$ Corrected item-total correlations (Item validity index) 
Azizah et al.

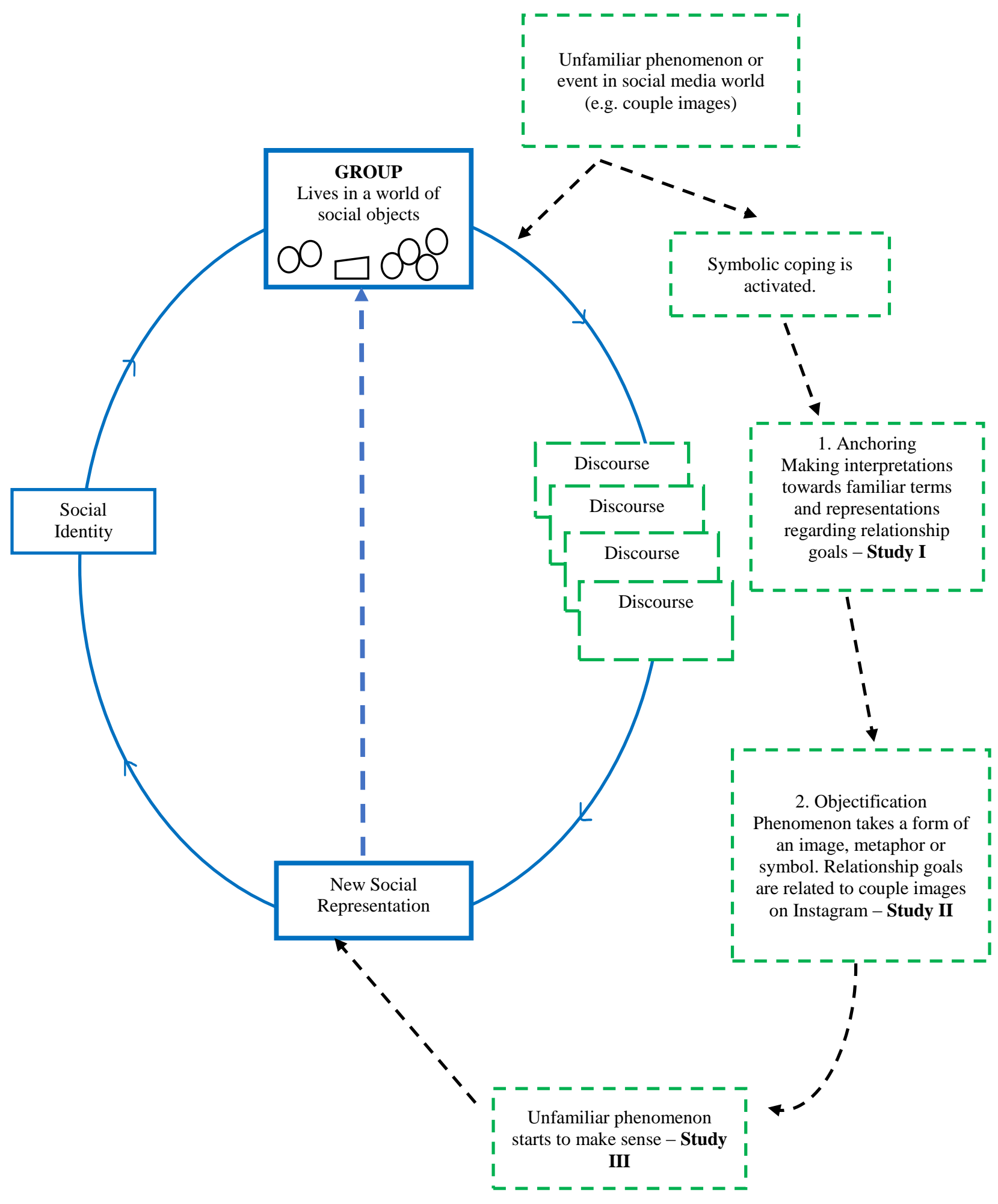

Figure 1 Theoretical framework 


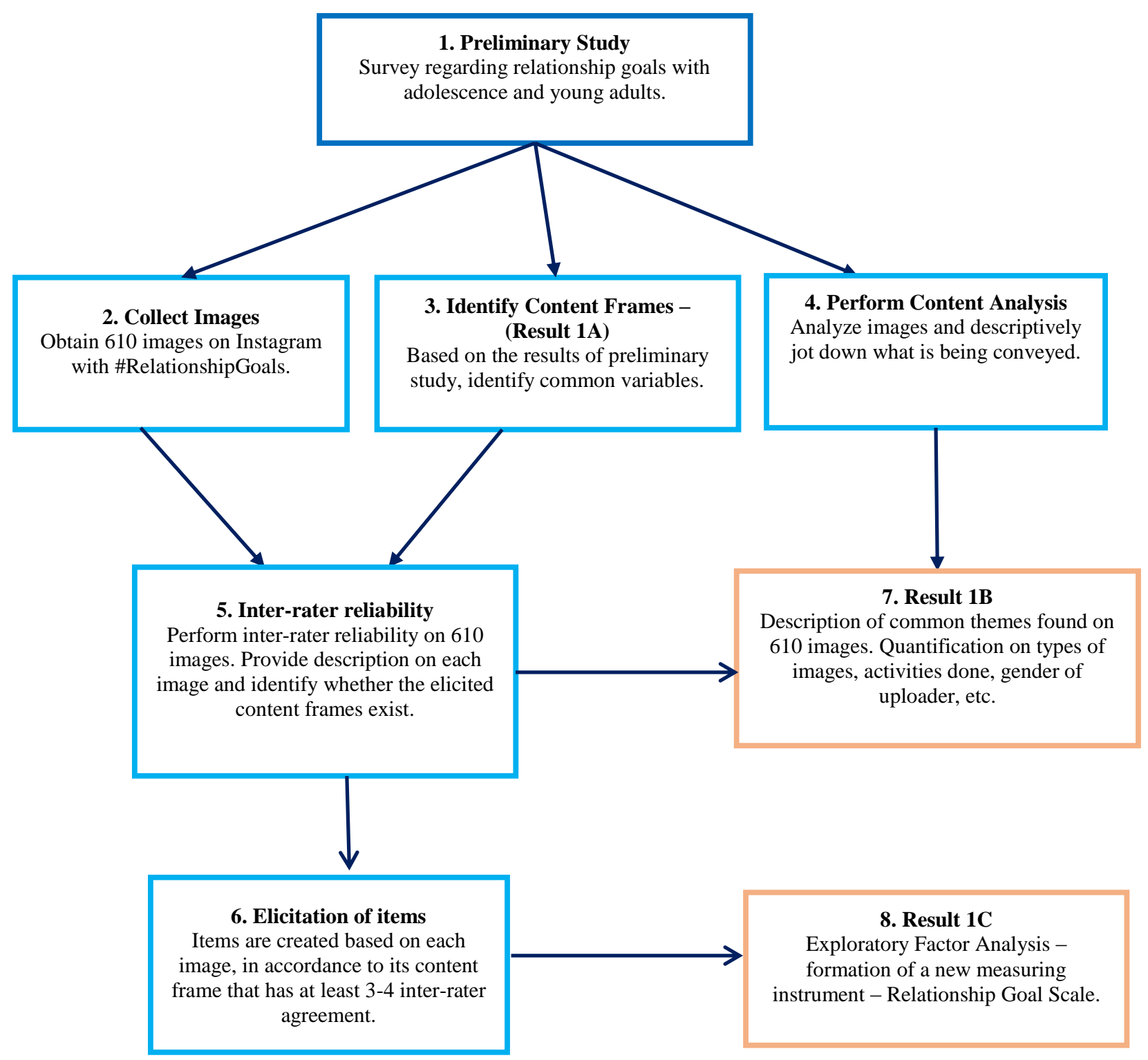

Figure 2 Research design and strategy

Based on the formed factors, researcher has conducted an internal consistency of items for the newly formed factors. The result is as presented in Table 2.

As Cronbach's Alpha reliability coefficient ranges between 0 and 1 , the closer the result is to 1.0 the greater the internal consistency of the factor. Based on the result of Table 2, the newly formed factor has Cronbach's Alpha value closing up to 1.0 ( $\alpha$ Factor 1 $=0.966, \alpha$ Factor $2=0.809, \alpha$ Factor $3=0.847$ ) which can be categorized as excellent and good criteria, respectively [30].
With regards to Figure 2, there are 3 main steps that are taken to conduct the research study: (1) preliminary study, (2) content analysis and (3) exploratory factor analysis. Primarily, researcher spread online questionnaires to obtain descriptive information regarding goals possessed by young adults. Commonalities between responses are categorized within one group of response creating a specific content frame. The term used to name the content frame and its operationalized definition is discussed with colleagues. Secondarily, the result of the content frames was coded onto the images and captions with \#RelationshipGoals on Instagram. 
Researchers seeks out commonalities among 4 interraters and identify how many images are in agreement for each content frame. Finally, the commonality found among 610 images based on each content frame was used to elicit items in order to construct a new scale: Relationship Goal Scale.

\section{Results}

\subsection{Study I-preliminary study}

Within this study, from a sample of $N=155$, the demographic variables of interest are age, gender, last education, domicile, last education degree, romantic relationship experience and status and Instagram usage. The result of the study indicates that 155 participants are within the age range of 20-25 $(M=$ 21.6), consist of 43 males, 111 females and 1 other in which 74 participants living in Jakarta, 2 participants living in Bogor, 5 participants living in Depok, 20 participants living in Tangerang, 28 participants living in Bekasi, 18 participants living in Bandung and 8 participants categorized as Others (i.e. Surabaya, Medan, Palembang, Sidoarjo, Malang, Pinrang). Most of the participants are high school graduates $(N=83)$, have had romantic relationship experience $(N=147)$, are currently in a romantic relationship $(N=87)$, are Instagram user $(N=149)$ and uses Instagram frequently $(N=71)$.

The result of open-ended questions related to goals possessed by young adults indicates that most individuals strive to accomplish is employment goals $(N=85)$ followed by educational goals $(N=54)$, marriage goals $(N=52)$, partner goals $(N=33)$, family goals $(N=32)$, etc. Finding a significant other becomes the third most common goals found which indicates that romantic relationship becomes a prevalent goal among young adults $(M=21.61, \mathrm{SD}=$ $1.07, N=155$ ). As for desired goals within a romantic relationship, the most commonly found response is marriage $(N=59)$ followed by characteristics of partner $(N=53)$ and mutual understanding $(N=44)$.

In relation to the significance of images with \#RelationshipGoals, the result yield to a finding in which most participants believe that images with \#RelationshipGoals convey a message related to the kind or type of ideal relationship that is often coveted by others in which people expect to happen to them $(N=21)$, while some believe that the uploader of these images has a goal to show off or boast their relationship to their viewers $(N=20)$ and others believe that uploaders of these images are trying to describe the state of their relationship (e.g. the image conveys goals within their relationship, the relationship is going well, partners love and care for each other, romantism, etc.) $(N=17)$.

The result of thematic analysis related to desired goals yield to the formation of 12 content frames based on similar responses found: (1) Take and Give, (2) Acceptance by partner, family and social circle, (3) Co-joint Activity, (4) Commitment, (5) Selfexploration, (6) Relationship Development, (7) Teamwork, (8) Partner's Characteristics, (9) Value, (10) Cogitation, (11) Brings Positive Impact and (12) Sexual Activity. Most of the responses reside on Take and Give content frame (38 responses) followed by Value (17 responses) and Relationship Development (12 responses). The content frame Take and Give consists of responses such as mutual support, mutual selves building or dream flourishing, mutual help, know each other better, mutual understanding, mutual succumb, etc. Meanwhile, the content frame Value consists of responses such as commitment, happy life, harmony, sincerity, simplicity, prosperity, loyalty, earnestness, honesty, etc. Whereas the content frame Relationship Development consists responses such as long-lasting relationships, healthy relationships, good relationships, developing relationships, relationships that more than just girl/boyfriends, etc.

\subsection{Study II-content analysis}

Within this study, from a sample of $N=610$ images, the demographic variables of interest are the gender of the uploader, their ethnicity and types of images posted. The uploaders are mostly female $(N=436)$ with 156 male and 18 images considered as others due to the fact that the account is for both couples or a business account. Most of the uploaders are of Western culture $(N=425)$ and the most salient images are couple-image $(N=220)$ followed by couple-selfieimage $(N=159)$ and objectification $(N=98)$.

The result of inter-rater reliability indicates that most of the images depict content frame Co-joint Activity with a total of 310 images exhibiting activities carried out together with a partner. The activities found within the image range from spending time together by watching a sports match on television, having a meal together, going on date nights, cooking together, exercising together to having an adventure together by traveling to places they have been to and never have been to before.

Furthermore, the second most commonly found theme within the result of the content analysis is Sexual Activity with a total of 233 images exhibiting 
an individual's need to physically connect with their partner. These activities range from touching partner's fingers or hands, holding partner's hands, sitting side by side with or without bodies close together, hugging shoulders or waist with or without bringing bodies close together, kissing forehead, cheeks or lips with or without bringing bodies close together, closely hugging each other to touching sensual body parts (i.e. buttocks). According to Abraham and Rahardjo [31], these behaviors are categorized as premarital sexual behavior. The result of content analysis reveals that around $38.2 \%$ of uploaders engage in the premarital sexual behavior.

Meanwhile, the third most commonly found theme within the result of the content analysis is Partner's Characteristics with a total of 115 images describing traits and characteristics desired by an individual in his/her partner. The result ranges from having a partner who can make one laugh, would do female activities such as masking and manicurepedicure, become best friends, invest their time and support, become an inspiration to having common values and religious beliefs. The fourth most commonly found theme within the result of the content analysis is Relationship Development with a total of 78 images describing an individual's desire for the relationship to progress towards a more serious phase (i.e. companionship, engagement, marriage, kinship, etc.). The result ranges from relationship progressing more than 6 months, talking about the next step in the relationship, becoming more than just lovers but also best friends to getting engaged and married as well as raising children. For the fifth most commonly found theme, the result of content analysis reveals Cogitation content frame with a total of 70 images describing small or big gestures carried out by an individual for his/her partner. The result ranges from having surprise date nights, celebrating special moments together to small gestures from a partner such as preparing food, buying flowers, etc. for no apparent reason.

As for the sixth most commonly found theme, the result of content analysis reveals Value content frame with a total of 48 images describing common beliefs held by a partner and / or both partners in a romantic relationship. The result ranges from valuing loyalty, growth, maturity, good communication, respect, compromising parent's successful relationship to religious beliefs held by partners. The seventh most commonly found theme within the result of the content analysis is Commitment content frame with a total of 43 images describing an individual's desire to take a more serious responsibility in his/her relationship with her partner. The result ranges from staying loyal to partner's initiative in make the relationship more serious (e.g. proposal, engagement, marriage). The eighth most commonly found theme within the result of the content analysis is Brings Positive Impact with a total of 30 images describing positive things that result from a relationship with one's partner. The result ranges from bringing a positive influence on each other, pushing out of comfort zone, making partner become a better version of oneself to bringing positive influence for surrounding environment.

For the ninth commonly found a theme, the result of content analysis reveals Teamwork content frame with a total of 27 images describing partners working together to achieve common goals through good communication, solving problems together, setting common goals, etc. The result ranges from working out problems together to reach separate as well as common goals, building a business together, putting in the same effort in maintaining the relationship to working together to build a future together (e.g. marriage, a house, raising children). The tenth commonly found theme within the result of content analysis is Take and Give with a total of 21 images describing mutual behavior exhibited by each partner - each would receive and give something for one another. The result ranges from making time for each other, supporting and motivating one another, taking care of one another to empowering and enhancing each other to reach their full potential. The eleventh commonly found theme within the result of content analysis is Self-exploration content frame with a total of 13 images describing an individual's desire to be able to understand him/herself in depth, to know new things about him/herself, to be authentic and be able to express who he/she is within the relationship. The results range from wanting to be oneself within the relationship, being able to know more about oneself in partner's present, being able to grow as separate individuals to challenging oneself to appreciate the difference between each other. Finally, the twelfth most commonly found theme within the result of the content analysis is Acceptance by partner, friends and social circle content frame with a total of 4 images describe an individual's desire to be accepted within the life and surrounding environment of his/her partner. The results range from wanting to be accepted for one's shortfalls and cultural backgrounds, accepted by partner and social circle (e.g. friends and family) to spending time with partner's social circle. 
3.3Study III-exploratory factor analysis

Within this study, from a sample of $N=367$, the demographic variables of interest are age, gender, domicile, ethnicity, last education degree, romantic relationship experience, and status. Those informations are vital in controlling the sample of participants taken from the population. The result of the study indicates that 367 participants are within the age range of 20-35 $(M=22.00)$, consist of 79 male and 288 female participants in which 197 participants live in Jakarta, 26 participants live in Bogor, 29 participants live in Depok, 71 participants live in Tangerang and 44 participants live in Bekasi. Most of the participants are Javanese $(N=130)$, high school graduates $(N=187)$, have all experienced romantic relationship and are mostly in a romantic relationship $(N=218)$.

Based on the result of Table 3, KMO value exhibits an excellent criterion that is suitable for conducting factor analysis $(K M O=0.945)$ with a significant model depicted from Bartlett's Test of Sphericity ( $p$ $<0.05$ ). However, based on the communalities table, there are 2 items that are unable to extract into factors as their extraction value is less than $50 \%$. Extraction value should at least explain $50 \%$ or above of the variance in extraction for each item. Often, researchers eliminate items with communalities less than 0.20 [32]. However, researcher feels that extraction value should at least be $50 \%$ or greater showing that the variance does not occur by chance and items are statistically grouped based on similarities.

With this, Table 4 indicates that item 17-SE with extraction value $0.499,29-\mathrm{SE}$ with extraction value 0.424 and item 65-POS with extraction value 0.435 should be removed from factor analysis-it indicates that, respectively, as much as $50.1 \%, 57.6 \%$ and $56.5 \%$ of these items are extracted by chance. Furthermore, based on Eigenvalue, 12 factors have been extracted as produce an Eigenvalue $>1.000$ [21]. The formation of these factors has a total cumulative variance of $66.67 \%$.

Based on the result of quartimax rotation, there are 45 items that can be loaded into 3 different factors. The 3 formed factors with their items are as presented in Table 5.

In accordance with Table 5, there are 3 factors that are formed from the result of quartimax rotation. Factor 1 has a correlation value of 0.956 , Factor 2 has a correlation of 0.769 and Factor 3 has a correlation value of $0.643(r>0.5)$-correlation value indicates an existence of the factors. Factor 1 consists of 34 items from content frames Take and Give, Commitment, Self-exploration, Relationship Development, Teamwork, Partner's Characteristics, Value, Cogitation, Brings Positive Impact and Acceptance. As for Factor 2, it consists of 5 items from content frame Sexual Activity. Meanwhile, Factor 3 consists of 6 items from content frame Value.

\section{Discussion}

4.1Study I-preliminary study

The result of Study I is aimed at answering Research Question 1. Based on frequency analysis, the most commonly desired goals are marriage followed by partner's characteristics and mutual understanding. In relation to the concept of relationship flourishing, a eudemonic process takes place within a relationship in which satisfaction or quality of relationship is gained as a means of development from both partners in terms of (1) meaning an individual has for his/her own life, (2) personal growth which includes enhancement in one's own potentials, character, knowledge, etc. (3) shared goals between partners, (4) relational giving as a means of prioritizing the partner for his/her own benefit, (5) personal expressiveness and (6) engagement which refers to a sense of flow experienced within the relationship [33]. The content frame Take and Give include responses that are related to the fourth dimension of relationship flourishing (i.e. relational giving), in which it describes partner's motivation to give or sacrifice something (e.g. time, attention, etc.) in order to ensure the best for the other. Meanwhile, the content frame Value includes responses that are related to the first dimension (i.e. meaning) in which individuals create meaning within their own lives, specifically in the realm of their romantic relationship (e.g. honesty, simplicity, commitment, consistency, etc.). Through the values individuals withhold, it serves as a source of meaning in life [34]. Values are the base of an individual's decision to act in the right or wrong way-thus, as it helps give a sense of clarity as to what the individual is living for and helps guide their actions in every aspect of their lives, it is only logical that the content frame becomes a salient aspect of goals within romantic relationship [34].

As for the content frame Relationship Development, it includes responses that are related to the sixth dimension (i.e. engagement) in which individuals desire the relationship to go well. It can be achieved when partners become engaged within the activities 
that they conduct together such that they experience a state of flow as they lose awareness of the time they spent together, which eventually leads to a positive relationship outcome (e.g. higher relationship quality) [35]. Furthermore, the content frame Teamwork includes responses that are related to the third dimension (i.e. goal sharing) in which individuals desire to work out through problems together, reach goals together, synchronize each other's thoughts, agree in the manner of raising and educating future children, etc. The effort that partners have put into the relationship through their cooperation can transcend to not only relationship satisfaction but also individual satisfaction [33]. In addition, Selfexploration includes responses that are related to the second dimension (i.e. personal growth) in which individuals desire to enhance their own characteristics through their interaction with their partners (e.g. improving oneself, exploring each other's shortcomings and advantages, able to be one's own self, etc.). By being able to expand oneself in various aspects while being challenged by partners to do new forms of activities, it can lead to positive relationship outcomes [35].

Moreover, Study I revealed that most young adults place similar significance towards \#RelationshipGoals imagery. Most of the participants believe that \#RelationshipGolas imagery resembles a relationship that is often coveted by others in which people expect to happen to them, followed by a belief that these uploaders are showing off their relationship and lastly, uploaders are expressing the state of their relationship as having actually reached the desired goals. It indicates that these images do exhibit the types of goals that an individual place for his/her own relationship.

\subsection{Study II-content analysis}

The result of Study II is aimed to answer Research Question 2. Through content analysis, it was revealed that the most commonly found theme / content frame within \#RelationshipGoals imagery is Co-joint Activity. Meanwhile, the second most commonly found theme is Sexual Activity followed by Partner's Characteristic, Relationship Development, Cogitation, Value, Commitment, Brings Positive Impact, Teamwork, Take and Give, Self-Exploration and Acceptance by partner, family and social circle. Without a doubt, the emergence of content frame $\mathrm{Co}$ joint Activity is salient within these images as human beings have the need to be connected with other people. In relation to self-determination theory [36], which states that human motivation function on three innate psychological needs such as competence, autonomy, and relatedness, an individual's desire to feel connected and acquire a sense of belongingness would exhibit behaviors that are related to doing activities together with the person most significant within his/her life (i.e. Co-joint Activity content frame).

In relation to Sternberg's Triangular Theory of Love [37], the three different components of love reveal itself in the content analysis result. In accordance with Sternberg's components of love, intimacy is depicted within the first commonly found theme (i.e. Co-joint Activity) as well as Cogitation and Take and Give content frame. This component depicts partners' closeness, support, love and sharing behavior towards one another - it helps create a strong bond between two individuals'. Related to the results of this content frame, by spending time with partner doing activities that both have an interest in, it helps build up closeness between one another. An individual is able to know more about their partner and has a better sense of who their partner is, what are their likes, dislikes, hobbies, etc.

Table 3 KMO and bartlett's test

\begin{tabular}{lll}
\hline Index & & Value \\
\hline Kaiser-Meyer-Olkin & Measure of Sampling & .945 \\
Adequacy. & & 15783.564 \\
& & 2016 \\
Bartlett's Test of Approx. Chi-Square & $d f$ & .000 \\
Sphericity & $p$ & \\
\end{tabular}

Table 4 Communalities

\begin{tabular}{|c|c|c|c|c|c|c|c|c|}
\hline Item & Initial & Extraction & Item & Initial & Extraction & Item & Initial & Extraction \\
\hline 1-TG & 1.000 & .622 & 23-SE & 1.000 & .609 & 42-VAL & 1.000 & .559 \\
\hline 4-TG & 1.000 & .540 & 26-SE & 1.000 & .542 & 45-VAL & 1.000 & .609 \\
\hline 7-TG & 1.000 & .662 & 29-SE & 1.000 & .424 & 47-VAL & 1.000 & .613 \\
\hline 10-TG & 1.000 & .666 & 18-REL & 1.000 & .737 & 51-VAL & 1.000 & .783 \\
\hline 13-TG & 1.000 & .610 & 21-REL & 1.000 & .738 & 55-VAL & 1.000 & .735 \\
\hline 2-SA & 1.000 & .723 & 24-REL & 1.000 & .621 & 58-VAL & 1.000 & .806 \\
\hline 5-SA & 1.000 & .547 & 27-REL & 1.000 & .693 & 61-VAL & 1.000 & .680 \\
\hline 8-SA & 1.000 & .599 & 30-REL & 1.000 & .738 & 64-VAL & 1.000 & .574 \\
\hline
\end{tabular}


Azizah et al.

\begin{tabular}{|c|c|c|c|c|c|c|c|c|}
\hline Item & Initial & Extraction & Item & Initial & Extraction & Item & Initial & Extraction \\
\hline $11-\mathrm{SA}$ & 1.000 & .770 & $31-\mathrm{T}$ & 1.000 & .502 & $48-\mathrm{COG}$ & 1.000 & .739 \\
\hline $14-\mathrm{SA}$ & 1.000 & .645 & $34-\mathrm{T}$ & 1.000 & .582 & $52-\mathrm{COG}$ & 1.000 & .555 \\
\hline 3-CA & 1.000 & .674 & $37-\mathrm{T}$ & 1.000 & .744 & $56-\mathrm{COG}$ & 1.000 & .667 \\
\hline 6-CA & 1.000 & .606 & $40-\mathrm{T}$ & 1.000 & .709 & 59-COG & 1.000 & .687 \\
\hline 9-CA & 1.000 & .686 & $43-\mathrm{T}$ & 1.000 & .771 & $62-\mathrm{COG}$ & 1.000 & .682 \\
\hline $12-\mathrm{CA}$ & 1.000 & .640 & 32-PC & 1.000 & 609 & 49-POS & 1.000 & .785 \\
\hline 15-CA & 1.000 & .569 & 35-PC & 1.000 & .525 & 53-POS & 1.000 & .559 \\
\hline 16-COM & 1.000 & 609 & 38-PC & 1.000 & .616 & 65-POS & 1.000 & .435 \\
\hline 19-COM & 1.000 & .584 & 41-PC & 1.000 & .693 & 66-POS & 1.000 & .700 \\
\hline 22-COM & 1.000 & .715 & 44-PC & 1.000 & .688 & 67-POS & 1.000 & .720 \\
\hline 25-COM & 1.000 & .709 & 46-PC & 1.000 & .681 & 50-АССРТ & 1.000 & .685 \\
\hline 28-COM & 1.000 & .811 & 33-VAL & 1.000 & .727 & 54-АCСРТ & 1.000 & .666 \\
\hline 17-SE & 1.000 & .499 & 36-VAL & 1.000 & .711 & 57-АCCPT & 1.000 & .731 \\
\hline \multirow[t]{2}{*}{ 20-SE } & 1.000 & .593 & 39-VAL & 1.000 & .680 & 60-АCCPT & 1.000 & .695 \\
\hline & & & & & & 63-АCCPT & 1.000 & .627 \\
\hline
\end{tabular}

Notes. $\mathrm{TG}=$ Take and Give, $\mathrm{SA}=$ Sexual Activity, $\mathrm{CA}=$ Co-joint Activity, $\mathrm{COM}=$ Commitment, $\mathrm{SE}=\mathrm{Self}$-exploration, $\mathrm{REL}=$ Relationship Development, $\mathrm{T}=$ Teamwork, $\mathrm{PC}=$ Partner's Characteristics, VAL $=$ Value, $\mathrm{COG}=\mathrm{Cogitation}, \mathrm{POS}=\mathrm{Brings}$ Positive Impact, ACCPT = Acceptance. Red colored text indicates that the item will be removed from factor analysis.

Table 5 Quartimax rotation results

\begin{tabular}{|c|c|c|}
\hline \multicolumn{3}{|c|}{ Factor 1:Psychological intimacy goal } \\
\hline Item no & Descriptor & $\begin{array}{l}\text { Factor } \\
\text { loading }\end{array}$ \\
\hline 7-TG & $\begin{array}{l}\text { Bisa menjaga satu sama lain adalah suatu hal yang saya cari dalam hubungan romantis. } \\
\text { (Being able to look after each other is something I look for in a romantic relationship.) }\end{array}$ & 0.512 \\
\hline 10-TG & $\begin{array}{l}\text { Dalam hubungan romantis, saya ingin dapat saling meningkatkan potensi masing-masing. } \\
\text { (In a romantic relationship, I want to be able to improve each other's potential.) }\end{array}$ & 0.537 \\
\hline 22-COM & $\begin{array}{l}\text { Dalam hubungan romantis, saya ingin pasangan dan saya setia terhadap satu sama lain. } \\
\text { (In a romantic relationship, I want my partner and I am faithful to each other.) }\end{array}$ & 0.760 \\
\hline 25-COM & $\begin{array}{l}\text { Saya ingin pasangan dan saya tetap bersama-sama melalui suka dan duka. } \\
\text { (I want my partner and I stay together through joy and sorrow.) }\end{array}$ & 0.803 \\
\hline 23-SE & $\begin{array}{l}\text { Saya ingin pasangan menunjukkan kepada saya bahwa saya dapat mencapai apapun yang } \\
\text { saya tetapkan / inginkan. } \\
\text { (I want my partner to convince me that I can achieve whatever I set / want.) }\end{array}$ & 0.532 \\
\hline 24-REL & $\begin{array}{l}\text { Dalam hubungan romantis, saya berharap dapat melewati lebih dari } 6 \text { bulan bersama } \\
\text { pasangan. } \\
\text { (In a romantic relationship, I hope to pass more than } 6 \text { months with my partner.) }\end{array}$ & 0.687 \\
\hline 27-REL & $\begin{array}{l}\text { Hubungan dengan pasangan yang berkembang menjadi hubungan persahabatan adalah } \\
\text { suatu hal yang saya cari dalam hubungan romantis. } \\
\text { (Relationships with a partner who develop into friendly relationships is the thing I look for } \\
\text { in romantic relationships.) }\end{array}$ & 0.507 \\
\hline 30-REL & $\begin{array}{l}\text { Saya ingin tumbuh tua bersama pasangan. } \\
\text { (I want to grow old with my partner.) }\end{array}$ & 0.705 \\
\hline $34-\mathrm{T}$ & $\begin{array}{l}\text { Dalam hubungan romantis, saya ingin bekerja sama dengan pasangan untuk mencapai } \\
\text { tujuan bersama dan pribadi. } \\
\text { (In a romantic relationship, I want to work with my partner to achieve common and } \\
\text { personal goals.) }\end{array}$ & 0.709 \\
\hline $37-\mathrm{T}$ & $\begin{array}{l}\text { Dalam hubungan romantis, saya ingin pasangan dan saya menyelesaikan permasalahan } \\
\text { kita bersama } \\
\text { (In a romantic relationship, I want my spouse and I to solve our problems together.) }\end{array}$ & 0.832 \\
\hline $40-\mathrm{T}$ & $\begin{array}{l}\text { Dalam hubungan romantis, saya ingin pasangan dan saya melakukan upaya yang sama } \\
\text { dalam menjaga hubungan } \\
\text { (In a romantic relationship, I want my spouse and I to make the same effort in maintaining } \\
\text { the relationship.) }\end{array}$ & 0.828 \\
\hline $43-\mathrm{T}$ & $\begin{array}{l}\text { Saya ingin pasangan dan saya bekerja sama dalam membangun masa depan bersama } \\
\text { (seperti, pernikahan, rumah, membesarkan anak, dll). } \\
\text { (I want my spouse and I to work together in building a common future (like, marriage, } \\
\text { home, raising children, etc.)) }\end{array}$ & 0.686 \\
\hline
\end{tabular}




\begin{tabular}{|c|c|c|}
\hline \multicolumn{3}{|c|}{ Factor 1:Psychological intimacy goal } \\
\hline Item no & Descriptor & $\begin{array}{l}\text { Factor } \\
\text { loading }\end{array}$ \\
\hline 32-PC & $\begin{array}{l}\text { Dalam hubungan romantis, saya mencari pasangan yang bisa membuat saya tertawa. } \\
\text { (In a romantic relationship, I am looking for a partner who can make me laugh.) }\end{array}$ & 0.660 \\
\hline 35-PC & $\begin{array}{l}\text { Saya mencari pasangan yang ingin berinvestasi dalam diri saya dan mendukung visi saya. } \\
\text { (I am looking for a partner who wants to invest in me and support my vision.) }\end{array}$ & 0.540 \\
\hline 38-PC & $\begin{array}{l}\text { Saya mencari pasangan yang menantang saya dengan cara yang positif. } \\
\text { (I am looking for a partner who challenges me in a positive way.) }\end{array}$ & 0.729 \\
\hline 41-PC & $\begin{array}{l}\text { Dalam hubungan romantis, saya menginginkan pasangan yang bisa menjadi sahabat } \\
\text { saya. } \\
\text { (In a romantic relationship, I want a partner who can be my best friend.) }\end{array}$ & 0.780 \\
\hline 44-PC & $\begin{array}{l}\text { Saya ingin memiliki pasangan yang dapat menginspirasi saya } \\
\text { (I want to have a partner who can inspire me.) }\end{array}$ & 0.807 \\
\hline 46-PC & $\begin{array}{l}\text { Saya mencari pasangan yang akan berdoa untuk kesejahteraan saya. } \\
\text { (I am looking for a couple who will pray for my welfare.) }\end{array}$ & 0.676 \\
\hline 33-VAL & $\begin{array}{l}\text { Dalam hubungan romantis, komitmen adalah suatu nilai yang saya hargai. } \\
\text { (In a romantic relationship, commitment is a value I appreciate.) }\end{array}$ & 0.806 \\
\hline 36-VAL & $\begin{array}{l}\text { Bisa berkembang dan menjadi lebih dewasa adalah suatu nilai yang saya hargai dalam } \\
\text { hubungan romantis. } \\
\text { (Being able to grow and become more mature is a value that I appreciate in romantic } \\
\text { relationships.) }\end{array}$ & 0.826 \\
\hline 39-VAL & $\begin{array}{l}\text { Dalam hubungan romantis, komunikasi yang baik adalah dasar dari kepercayaan, } \\
\text { kejujuran dan kesetiaan. } \\
\text { (In a romantic relationship, good communication is the basis of trust, honesty and loyalty.) }\end{array}$ & 0.801 \\
\hline 42-VAL & $\begin{array}{l}\text { Dalam hubungan romantis, kompromi adalah suatu nilai yang saya hargai. } \\
\text { (In a romantic relationship, compromise is a value I appreciate.) }\end{array}$ & 0.693 \\
\hline 45-VAL & $\begin{array}{l}\text { Rasa hormat adalah suatu nilai yang saya cari dalam hubungan romantis. } \\
\text { (Respect is a value I look for in a romantic relationship.) }\end{array}$ & 0.668 \\
\hline $56-\mathrm{COG}$ & $\begin{array}{l}\text { Isyarat kecil dari pasangan adalah suatu hal yang berharga (seperti meninggalkan pesan, } \\
\text { membawa makanan, mengirim teks lucu, dll). } \\
\text { (Small gestures from couples are a valuable thing (like leaving messages, bringing food, } \\
\text { sending funny texts, etc.).) }\end{array}$ & 0.630 \\
\hline 59-COG & $\begin{array}{l}\text { Dalam hubungan romantis, kejutan dan isyarat kecil dibutuhkan untuk menjaga } \\
\text { romantisme. } \\
\text { (In romantic relationships, surprises and small gestures are needed to keep romance.) }\end{array}$ & 0.563 \\
\hline 62-COG & $\begin{array}{l}\text { Saya merasa spesial saat pasangan memberi kejutan tanpa alasan tertentu. } \\
\text { (I feel special when couples give surprise for no particular reason.) }\end{array}$ & 0.597 \\
\hline 49-POS & $\begin{array}{l}\text { Dalam hubungan romantis, saya ingin membawa pengaruh positif untuk satu sama lain. } \\
\text { (In a romantic relationship, I want to bring positive influence to each other.) }\end{array}$ & 0.879 \\
\hline 53-POS & $\begin{array}{l}\text { Saya ingin pasangan bisa mendorong saya untuk keluar dari zona nyaman saya. } \\
\text { (I want my spouse can push me to get out of my comfort zone.) }\end{array}$ & 0.515 \\
\hline 66-POS & $\begin{array}{l}\text { Saya ingin hubungan romantis saya membawa dampak positif bagi lingkungan sekitar. } \\
\text { (I want my romantic relationship to have a positive impact on the surroundings.) }\end{array}$ & 0.694 \\
\hline 67-POS & $\begin{array}{l}\text { Dalam hubungan romantis, ketika pasangan dapat memahami diri mereka masing-masing, } \\
\text { mereka dapat membawa pengaruh yang positif terhadap satu sama lain dan lingkungan } \\
\text { sekitar. } \\
\text { (In romantic relationships, when couples can understand themselves, they can give a } \\
\text { positive effect on each other and the surroundings.) }\end{array}$ & 0.726 \\
\hline 50-АCСРТ & $\begin{array}{l}\text { Dalam hubungan romantis, saya ingin diterima oleh pasangan meskipun memiliki } \\
\text { kekurangan. } \\
\text { (In a romantic relationship, I want to be accepted by a couple despite having a flaw.) }\end{array}$ & 0.796 \\
\hline 54-ACCPT & $\begin{array}{l}\text { Saya ingin diterima oleh keluarga pasangan. } \\
\text { (I want to be accepted by my partner's family.) }\end{array}$ & 0.764 \\
\hline 57-АCCPT & $\begin{array}{l}\text { Dalam hubungan romantis, saya ingin menjadi bagian dari semua lingkaran sosial } \\
\text { pasangan (seperti pertemanan, kekeluargaan, dsb.). } \\
\text { (In a romantic relationship, I want to be part of all the social circles of the couple (like } \\
\text { friendship, kinship, etc.).) }\end{array}$ & 0.550 \\
\hline
\end{tabular}


Azizah et al.

\begin{tabular}{llc}
\hline & \multicolumn{1}{c}{ Factor 1:Psychological intimacy goal } & Factor \\
\hline Item no & Descriptor & 0.761 \\
\hline \multirow{2}{*}{ 63-ACCPT } & $\begin{array}{l}\text { Saya ingin pasangan saya menghargai latar belakang budaya saya. } \\
\text { (I want my partner to appreciate my cultural background.) }\end{array}$ & $\begin{array}{l}\text { loading } \\
\text { (I }\end{array}$
\end{tabular}

\begin{tabular}{llc}
\hline & & \multicolumn{1}{c}{ Factor 2:Sexual activity goal } \\
\hline Item no & Descriptor & $\begin{array}{c}\text { Factor } \\
\text { Loading }\end{array}$ \\
\hline 2-SA & $\begin{array}{l}\text { Saya dan pasangan sering mencium kening atau pipi satu sama lain secara tiba-tiba. } \\
\text { (Me and my spouse often kissed the forehead or cheek each other suddenly.) }\end{array}$ & 0.791 \\
5-SA & $\begin{array}{l}\text { Saya berpegangan tangan dengan pasangan di ruang publik. } \\
\text { (I held hands with my partner in the public sphere.) }\end{array}$ & 0.676
\end{tabular}

8-SA Saat sedang foto bersama pasangan, saya dan pasangan berdiri atau duduk berdampingan $\quad 0.637$ dengan tubuh saling berdekatan.

(While taking a photo together with my partner, me and my partner stand or sit side by side with the body close together.)

11-SA Saya dan pasangan sering memeluk satu sama lain secara tiba-tiba. (I and my spouse often hug one another suddenly.)

14-SA Kasih sayang dalam bentuk sentuhan fisik (seperti berpegangan tangan, berciuman, berpelukan, melakukan hubungan seksual, dsb) adalah suatu hal yang saya cari dalam hubungan romantis.

(Compassion in the form of physical touch (like holding hands, kissing, hugging, sexual intercourse, etc.) is something I look for in a romantic relationship.)

\begin{tabular}{lll}
\hline & & \multicolumn{1}{c}{ Factor 3: Religious beliefs goal } \\
\hline Item no & Descriptor & $\begin{array}{l}\text { Factor } \\
\text { Loading }\end{array}$ \\
\hline 47-VAL & $\begin{array}{l}\text { Hubungan romantis orang tua saya yang sukses menjadi panutan bagi saya. } \\
\text { (The successful romantic relationship of my parents became a role model for me.) }\end{array}$ & 0.505 \\
51-VAL & $\begin{array}{l}\text { Saya percaya bahwa agama merupakan fondasi dari hubungan romantis. } \\
\text { (I beliercourse, etc.) is something look for in a romantic relationship.) }\end{array}$ & 0.780
\end{tabular}

55-VAL Saya percaya bahwa ketika pasangan dan saya melibatkan Tuhan / agama dalam hubungan, 0.697 kami dapat mengatasi masalah bersama-sama.

(I believe that when my spouse and I involve God / religion in relationship, we can solve the problem together.)

58-VAL Membangun hubungan romantis yang didasari dengan nilai agama yang dianut oleh kedua 0.742 pasangan adalah suatu hal yang saya cari dalam hubungan romantis.

(Building a romantic relationship based on the religious values shared by a couple is something I look for in a romantic relationship.)

61-VAL Dalam hubungan romantis, saya memiliki pasangan yang menganut nilai agama yang sama seperti saya.

(In a romantic relationship, I have a spouse who shares the same religious values as me.)

64-VAL Aktivitas seksual (seperti berpegangan tangan, berciuman, berpelukan, hubungan seksual, 0.555 dan sebagainya) adalah suatu hal yang saya hindari dengan pasangan sebelum menikah. (Sexual activity (such as holding hands, kissing, hugging, sexual intercourse, etc.) is something I avoid with couples before marriage.)

Notes. $\mathrm{TG}=$ Take and Give, $\mathrm{SA}=$ Sexual Activity, $\mathrm{CA}=\mathrm{Co}$-joint Activity, $\mathrm{COM}=$ Commitment, $\mathrm{SE}=\mathrm{Self}$-exploration, $\mathrm{REL}=$ Relationship Development, $\mathrm{T}=$ Teamwork, $\mathrm{PC}=$ Partner's Characteristics, $\mathrm{VAL}=$ Value, $\mathrm{COG}=\mathrm{Cogitation}, \mathrm{POS}=\mathrm{Brings}$ Positive Impact, ACCPT $=$ Acceptance

Through quality time together, a partner can disclose information about themselves to their partner, which helps create an intimate bond. In relation to Cogitation content frame, small or big gestures that partners do one another serve as a form of effort given to keep the romance going. Through small surprises such as preparing food, planning a surprise 26 date night, anniversary celebration to buying flowers for no occasion, the partner would feel very special for all the attention given. In addition, through Take and Give, by being there for one's partner, showing support and investing one's own time to be with one's partner is another form of effort given to keep the bond and romance going. 
Furthermore, the second component of love that is also relevant to the result of the content analysis is a passion which is depicted within the second commonly found theme (i.e. Sexual Activity). This component depicts the drive that partners have towards each other in order to build the romance within their relationship [37] - it refers to feelings of sexual attraction and arousal towards one another. The existence of Sexual Activity content frame is in line with Sternberg's Triangular Theory of Love [37] that passion is an aspect needed within a romantic relationship. Activities such as holding partner's hands or fingers, sitting side by side with or without bodies close together, hugging shoulders or waist, kissing cheeks or lips to touching sensual body parts resemble the passion component of love. Lastly, the third component of love-commitmen-is depicted in the fourth and seventh most commonly found theme in content analysis (i.e. Relationship Development and Commitment, respectively). This component depicts partners' devotion towards one another such that the result of Relationship Development and Commitment exhibits results corresponding to Sternberg's defined component. Through images depicting boyfriend going down on one knee and proposing to girlfriend to couples throwing an engagement party serves as an indication that partners are willing to stay loyal to each other and are committed to embark on a long-term relationship.

However, there are some discrepancies exist between images of the same category. Photo 115 and Photo 230 exhibits 2 similar content frame: (1) Co-joint Activity and (2) Sexual Activity. Within Photo 115, the posted image exhibits couples last day of travel in which they are spending time together by the pool where the uploader is being carried on her boyfriend's shoulders. Meanwhile, Photo 230 exhibits an image of appreciation during their travel together in which the uploader praises his girlfriend's beauty to be equivalent to that of nature's. Moreover, the couple exhibits a different form of sexual activity in which the uploader's arm is being held by his girlfriend. These two photos also differ from that of Photo 335 and Photo 426 which has the same category of the content frame. Photo 335 exhibits couple travels together such that the memories they have created together are captured through the single photo shot. The image also exhibits a different form of sexual activity, one in which the uploader's girlfriend is bringing her body close to his - hugging from the back. As for Photo 426, the image resembles a different type of co-joint activity, a night spent together doing something that the uploader knows nothing about (i.e. playing billiard). The moment created was captured and uploaded as a way of showing appreciation for the fun night the uploader had with her boyfriend. In addition, the image exhibits a similar form of sexual activity to that of Photo 335 in which the uploader's boyfriend is bringing his body close to her.

Within the second most commonly found theme, sexual activity, Photo 96 and Photo 472 exhibits some discrepancies. In Photo 96, the uploader posted an image indicating her appreciation for the kiss on the cheek she got from her boyfriend. However, in Photo 472, the uploader has no caption other than hashtags used to express that she loves her boyfriend and simply by being hugged and kissed exhibits a goal she has achieved in her relationship. Furthermore, within Photo 334 and Photo 508, these images contain common content frame (Sexual Activity and Co-joint Activity). In Photo 334, the uploader posted the image as a means of showing that she misses her partner and has never felt such a strong emotion for anyone before him. The image was captured during one of their activities together and served as a memory through the hugs and kisses lingering in her thoughts. However, Photo 508 conveys a message related to the uploader's appreciation for the adventure they had together.

Moreover, for the third most commonly found theme, partner's characteristics, Photo 36, Photo 54, Photo 126 and Photo 172 exhibits some similarities such that the uploader is conveying a message that these types of characteristics (e.g. attention giver, puts a smile on their face, do feminine activities together, etc.) is what they consider to be a goal in their romantic relationship. However, Photo 126, the uploader has conveyed his message using a Meme in which a romantic relationship is compared to that of the relationship Pikachu, a cartoon character, has with ketchup-a comparison of a cartoon's relationship is used to indicate that relationship can be that simple; as simple as a love an individual has for food garnishes that with every food the individual eats, the ketchup should be present; as simple as what the individual does or where the individual goes, the partner should be present.

As for the fourth commonly found a theme, relationship development, Photo 4 and Photo 366 is commonly categorized within 2 content frames (relationship development and commitment). Nevertheless, these images exhibit some discrepancies in which Photo 4, the uploader is 
reminiscing to the first few years they have dated and looked back to see how far they have now reached10 years later and they are still together. Meanwhile, Photo 366 exhibits a message conveying the uploader's seriousness in taking a step further within his romantic relationship. The uploader is ready to commit to his girlfriend and take her hand in marriage in order to move on to the next stage of their relationship. The former is longing for the past memories they have created, and the latter is making changes and creating new memories. In addition, Photo 445 and Photo 479 is also commonly categorized within 2 content frames (relationship development and co-joint activity). Both images are posted by the same individual, however, the former captures the couple's travel moment in which the uploader posts the image as a form of appreciation for the amazing travel they had together. Furthermore, the appreciation is directed towards her boyfriend's action towards taking the next step in their relationship (i.e. progressing to marriage). Meanwhile, the latter image is a throwback image longing back to the memories they had created during their proposal travel in which the uploader is also showing appreciation for the presence of her partner.

\subsection{Study III-exploratory analysis}

Based on the result of Exploratory Factor Analysis, there are 3 factors formed from 64 items with a total of 45 items formed into 3 different factors. Factor 1 consists of 35 items from 10 different content frames Take and Give, Commitment, Self-exploration, Relationship Development, Teamwork, Partner's Characteristics, Value, Cogitation, Brings Positive Impact and Acceptance by partner, family and social circle. It has been found that intimacy and identity dating goals serve as a relevant factor in relationship satisfaction - participants who reported experiencing intimacy goals and perceived that their partners are more positive towards these goals experience a high level of satisfaction within their relationship [38]. Within this study, intimacy goals have been defined as dating behavior to fulfill the desire for mutual dependence, emotional attachment as well as sharing of intimate thoughts and feelings [38]. Furthermore, these goals fall under or are related to innate psychological needs possessed by human beings as a function of motivation [39]. According to SelfDetermination Theory, there are 3 fundamental types of needs in which intimacy goals fall under one of them - intimacy dating goals fall under relatedness need (i.e. desire to feel connected and acquire a sense of belongingness). Moreover, intimacy goals reveal that individuals exhibit a sense of exclusivity within a relationship in the form of self-disclosure, are in pursuit of commitment, emotional intimacy, and interdependence [38, 40]. Furthermore, there are 3 different types of positive relationship behavior that are exhibited once these innate psychological needs have been fulfilled (1) warmth which includes involvement, affection and love, (2) autonomy support which includes independent action, decisionmaking, support and respect for choice and personal decision-making and (3) structure which includes consistent and reliable behavior exhibited by partner [39]. In line with the findings of these studies and based on the result of EFA, the researcher would rename Factor 1 as Psychological Intimacy Goals.

Meanwhile, Factor 2 consists of 5 items residing within the content frame Sexual Activity. Young adults express the need for sexual activities or goals within their romantic relationship [40]. Within the study, participants were in the age range of $16-30$ years old $(N=208, M=23$ years, $S D=4.1,66 \%$ females) and as much as $44 \%$ were in a steady relationship with most of them having an average relationship age over 3 years $(M=3.4, S D=2.7)$. The study indicates that fulfillment and experimentation of sexual activities play an important role in emerging adult's developmental period. Therefore, it is only logical that the participants within this study and that conducted by Kelly, Zimmer-Gembeck and Boislard-P [40] show a resemblance in the things that they want to achieve within their relationship (i.e. sexual goals). The result of the study reveals that sexual dating goals paired with sexual behavior are found to be associated with sexual life satisfaction $\left(r^{2}=0.21\right)$. However, sexual dating goals alone were not found to be associated with sexual life satisfaction $\left(r^{2}=0.05\right)$. It indicates that dating goals along with consistent behavior are associated with functional outcomes such as life satisfaction [40]. In accordance with this study and based on the result of EFA, the researcher would rename Factor 2 as Sexual Goals.

As for Factor 3, there are 6 items that reside from the content frame Value. The items within this factor are related to religious values held by partners in their relationship. Religion plays an important role not only in marital relationship but also in the romantic relationship between dating individuals [41]. Many studies have found that religion is significantly correlated to marital satisfaction [42, 43]. Attendance at religious services was also reported to be associated with strong marriages, stability in relationship and engagement in healthy behavioral 
habits (e.g. lower rates of drug abuse and addiction) [44]. Religion becomes an important factor that influences relationship and serves as something that is valued by most individuals [41]. Furthermore, on dating college couples, belief and attitude similarities have been found to be linked with relationship satisfaction [11]-people tend to be attracted to those who share similar attitudes and/or values with them. The result of their study found that high perceived similarity in religious affiliation reported greater satisfaction than their counterparts [11]. Nevertheless, it would lead to greater satisfaction when these factors are deemed vital for the individuals themselves. In line with this, the result of the factor analysis reveals that religion serves as a salient aspect of relationship goal. This is evident in the types of items formed within Factor 3. With this, the researcher would rename Factor 3 as Religious Beliefs Goals.

Unfortunately, most theories related to love lack the explanation of the values in the form of religious beliefs. As have been previously stated, Sternberg's Triangular Theory of Love [37] only consists of 3 different types of components in which it can explain psychological intimacy goals and sexual goals. Most theories of love as having been stated by Zick Rubin and Elaine Hatfield (as cited in [37]) do not contain aspects of values held by each partner.

\section{General discussion}

In relation to social representation theory, the framework indicates that as a new phenomenon is bombarded into a group of individuals, people will start to make sense of it through the symbolic coping and anchoring the event into a common term. As a means of understanding the hashtag relationship goals, Study I was conducted to anchor researcher's understanding of what goals in a romantic relationship entails. By spreading questionnaires and obtaining open-ended responses, researcher was able to create 12 content frames through thematic analysis. Study II was conducted as a means of objectifying the term in forms of symbols or images. By conducting content analysis, researcher was able to gain an in-depth understanding of \#RelationshipGoals imagery. The existence of content frames is salient due to the process of discourse in which the goals within a romantic relationship become represented among young adults. Study III was conducted as a means of studying the represented goals among general groups of young adults.
The result within Study I emerge in Study II and III as young adults are bombarded with events regarding relationships from parents, peers, social media, etc. Within the advancement of technology and the spread of couple-images on social media, the newly formed phenomenon brings about a process of interpersonal communication among young adults in which they try to attach meaning towards it. The emergence of content frames in Study II and III serve as a result of social representation (i.e. objectification) in which the aspects that are important to sustain a relationship (e.g. intimacy, passion, commitment) is salient within both studies.

Within the result of Study I, it indicates that the content frame Take and Give serve as the most salient aspects of goals as it contained the most common responses. Meanwhile, the result of Study II indicates that the content frame Co-joint Activity is the most salient aspect of goals with 310 images. In relation to the concept of relationship flourishing, eudemonic process is a form of satisfaction that gives rise to a better relationship quality [33]. The related content frame Take and Give, Value, Relationship Development, Self-exploration and Teamwork serve as an important aspect in the relationship process that can give rise to a better relationship quality leading to a higher satisfaction and a decrease in relationship conflict $[10,11,33]$. However, the result of content analysis exhibits quality time together to be an important goal that young adults strive to accomplish. This might be due to the fact that during the process of the inter-rater reliability, most inter-raters focused their attention on the images portrayed instead of integrating the meaning of the caption with the image. The result of content analysis lead to the superficial aspect of the goals - such as spending time together by having date nights, travelling together, etc. instead of the most crucial part of the relationship; its process.

In addition, the result may be as such due to the fact that, goals can be of long-term (broad and abstract) or short-term (concrete and specific) [45]. Throughout the adaptation process of creating open-ended questions related to desired goals, researcher specifically asks "tujuan atau hasil akhir" which is directly translated as "end product". Participants correspond towards the end product or long-term aspect of the goals that they would want to achieve within their own romantic relationship. The longterm aspect of the goal resembles something in the long-future in which process and time are needed in order to achieve them (e.g. mutual understanding, 
marriage, commitment, etc.). Meanwhile, the most salient result that emerges from the images and caption with \#RelationshipGoals resemble aspects of goals within the short-term in which, at that specific instant, the uploader has reached his/her near-future goal of spending time with their partner and capturing the moment. As social media have become a fast-paced culture in which users require instant gratification from their posts $[46,47]$, based on the study conducted by Oloo [47] regarding instagratification, the result indicates that users upload photos on their social media so as their followers could comment on them. Uploaders have the need for instant gratification from their followers such that capturing moments at that instant and posting them on their timeline becomes an activity that brings them pleasure [47]-in which Fowers et. al. [33] stated to be a part of the hedonic aspect of satisfaction in a relationship (i.e. does not focus on the process but views the end result). In line with the post related to \#RelationshipGoals, social media has created a cycle of instant activities in which the images posted resemble only a portion of the uploader's life (either in the present or the future)capturing only a short version of desired goals within a romantic relationship.

Nevertheless, it should not be excluded that these are the goals most salient among young adults. It is to say that the norms related to goals within a romantic relationship can be about posting pictures with a partner just for the sake of it and having a sense that the uploader has achieved a relationship goal by just doing so. As has been indicated in the result of content analysis, Photo 96 and Photo 472 exhibits 2 images in which the uploader posts a picture of their kisses with their boyfriend and indicating that it's a sign of love - the uploaders are conveying a message that just by receiving kisses, it is all the they have hoped to achieve in their relationships and posting a picture of it is showing that they have achieved their intended goals. Furthermore, the images uploaded based on the content frame Co-joint Activity is usually a throwback image of partner's time out together or an appreciation post of the moment they spent together.

\section{Conclusion and future work}

What has been saliently found in the content analysis has revealed it within the factor analysis study. These present studies indicate that \#RelationshipGoals is socially represented among young adults by 12 content frames found in the preliminary study (Study I) as well as \#RelationshipGoals content analysis study (Study II) — which are nested within three newly formed factors of Relationship Goals Scale (Study III), i.e. (1) Psychological Intimacy, (2) Sexual Activities, and (3) Religious Beliefs.

Theoretically, this present study challenges Stephanie Coontz's [48] proposition that self-fulfillment or selfvalidation composes heavily contemporary marriage or romantic relationship. Coontz did argue that historically, marriage orientation has undergone shifting from social coordination (institutionalization) toward self-fulfillment (deinstitutionalization). Her analysis is also reinforced by Eli Finkel (as cited in [49]), which stated that, thanks to the humanistic psychology stream, there is an increasing "expectation that our spouse will help us grow, help us become a better version of ourselves, a more authentic version of ourselves." By applying two perspectives, i.e. the motivational pyramid of Abraham Maslow [50] and the social exchange paradigm, Finkel concluded that today's relationship satisfaction can be achieved by promoting "each other's personal growth". Coontz's and Finkel's remarks have been thought over a decade and a half ago when Beck and Beck-Gernsheim [51, p.8] stated that "whereas marriage was earlier first and foremost an institution sui generis raised above the individual, today it is becoming more and more a product and construct of the individuals forming it."

However, this present study found something different from the analysis and beliefs of Beck and Beck-Gernsheim, Coontz, and Finkel. Based on the Exploratory Factor Analysis (EFA), Factor 1 (Psychological Intimacy) of Relationship Goals actually includes two things, both (1) Aspects that are considered as important nuance in "previous/traditional/sociological oriented" marriage, i.e. Commitment/COM, Relationship Development/REL, Teamwork/T, Value/VAL, Cogitation/COG, Acceptance/ACCPT; and (2) Aspects of self-actualization or self-fulfillment or socalled "contemporary/individual oriented" marriage goals (i.e. Self-Exploration/SE, Take and Give/TG, Brings Positive Impact/POS). In EFA, both empirically can not be separated into two different categories of factors, but co-exist in one factor, i.e. the Psychological Intimacy.

The findings provide a new lens on how we should look at the orientation of the relationship in the present. Modern couples, at least those who are participants in this present study, do not just "take off" things that are considered valuable goal in 
marriage in previous periods. However, at the same time, they add to the weight of a self-realization goal in today's relationship. These findings are in line with the findings of Krems, Kenrick, and Neel [52] which suggested that "participants anticipate their self-actualizing to involve not only finding a desirable mate, but also retaining him or her" (p.8), and that "even these lofty outcomes (i.e., pursuing self-actualization) may be linked to biologically and socially relevant payoffs" (p.13).

Thus, this study provides a rebuttal to the assumptions that, generally, the contemporary relationship is dominated by self-actualization (the top element of the Maslow's pyramid [50]) as a superordinate parameter, potentially sacrificing or eroding intimacy (lower element). Proven that the domination is not the case. Both (intimacy and selfactualization) are not "competing" and outperforming each other. The study even found that, in addition to the fact that self-fulfillment and inherent expectations of "traditional marriage institutions" (commitment, acceptance, etc.) cannot be discretely discernible (in Factor 1 of EFA), two other factors that still very important in contemporary marriages are Sexual Activities and Religious Beliefs-which are considered "traditional relationship goals" by a number of romantic relationship researchers.

This present study suggests that self-actualization is not a new element that becomes a sufficient condition complementing sexual activity (Factor 2) in order to get relationship satisfaction. Already since 1978, Paxton and Turner [53, p.66] explained that "certain types of sexual attitudes and behaviors may be characteristic of self-actualizing females." Thus, in line with the predictions and the results of previous studies [52], self-actualization does not stand independent and become the ultimate relationship goal especially in the romantic one. Rather, on the contrary, through regression analysis (with sexual satisfaction as the dependent variable), selfactualization is found to be devoted to sexual activity [53], which has been robustly proved pivotal as a contributor to relationship satisfaction [54, 55]. Furthermore, religious beliefs, goals are found as Factor 3 of Relationship Goals. This is not surprising because politically, especially in Indonesia, religious beliefs, goals are considered important to be promoted by some parties in order to influence society and country through religious families as the agents [56].
Practically, the findings of this study suggest us to have a critical attitude that is wary of the flow of thought that would "individualize" a contemporary relationship and marriage. When not careful, we can recklessly place the "family/relationship vision" as a subordinate of "personal/career vision, selfactualization", for example, with the advice of "Marrying someone who supports your career or selfactualization." Relationship and marriage psychologists and counselors need to be very careful in issuing such suggestions. The romantic relationship, as revealed in the EFA of this present study, is more of a paradox of unified elements, where the "old orientation" and "new orientation" merge, "social institution" and "personal expectation" converge (see also Juneman and Rahardjo's study [57] on the diverse sexual values existing among college students). Especially in Indonesia, the one among the countries with the largest Muslim populations, the notion of "individualized marriage" [58] and "democratization of individualization processes" [51], based on the results of this study, have not been finding the right momentum to become a relationship zeitgeist even among social media users.

The result of this factor analysis of this present study mediates the debate between opinions which emphasize beliefs about the occurrence of individualized marriage and the results of Yodanis and Lauer [59, p.184] recently that "the majority of spouses engage in interdependent and integrated behaviors and that trends are not clearly on a trajectory toward individualization. Institutions, including formal and informal rules and taken-forgranted assumptions, do not change easily." We cannot deny that the tensions of institutionalizationdeinstitutionalization and sociologizationpsychologization of marriage really live together, paradoxically, perhaps in a mess in the relationship goals of modern society.

There are some suggestions for future work methodology. In addition to the process of content analysis, most of the \#RelationshipGoals imagery contains captions in English, Spanish, Italian, etc. The meaning of love might be lost in translation during the coding process that researcher and interraters have done. Therefore, it is strongly advised that future researchers are aware of such confounding variables by having an expert in languages help translate the meaning of these captions. 
The images obtained during the study has hashtag other than \#RelationshipGoals included in them. The researcher has no certain rule in the collection of images based on the types of hashtags that uploaders use. Nevertheless, these hashtags have their own meaning and representation embedded within them. With this, for future studies, researchers suggest that image collection should be tightly restricted in terms of language and how many hashtags are present.

The result of the study can be used by laypersons such as parents or professionals as a means of educating the younger generation on the significance or meaning behind the spread of couple images on Instagram.

\section{Acknowledgment}

None.

\section{Conflicts of interest}

The authors have no conflicts of interest to declare.

\section{References}

[1] B Solis, The hashtag economy. http://www.briansolis.com/2011/06/hashtag-this-theculture-of-social-media-is. 2011. Accessed 27 September 2017.

[2] In indonesia, facebook remains the most popular social site. https://www.emarketer.com/Article/IndonesiaFacebook-Remains-Most-Popular-SocialSite/1014126. Accessed 26 September 2017.

[3] Adam. Relationship Goals. http://knowyourmeme.com/memes/relationshipgoals?f ull=1. Accessed 26 September 2017.

[4] Flounoy M, Relationship goals: 8 traveling couples to follow on instagram. http://www.lifehack.org/500630/relationship-goals-8traveling-couples-to-follow-on-instagram. Accessed 26 September 2017.

[5] Levinson AH. The trouble with Relationship Goals. https://melmagazine.com/the-trouble-withrelationshipgoals-655ccc55a337. Accessed 27 September 2017.

[6] Feist J, Feist GJ. Theories of personality. McGrawHill Education; 2008.

[7] Rankin S. The truth about celebrity relationship goals. http://www.eonline.com/news/829177/thepsychology-of-celebrity-couples-arerelationshipgoals-killing-our-romances. Accessed 27 September 2017.

[8] Emery LR. 7 Relationship goals for 2017 that are realistic https://www.bustle.com/articles/199125-7relationship-goals-for-2017-that-are-realistic-gamechangers. Accessed 26 September 2017.
[9] Wesner KA. Social comparison of romantic relationships: the influence of family, friends, and media. Iowa State University; 2008.

[10] Avivi YE, Laurenceau JP, Carver CS. Linking relationship quality to perceived mutuality of relationship goals and perceived goal progress. Journal of Social and Clinical Psychology. 2009; 28(2):13764.

[11] Lutz-Zois CJ, Bradley AC, Mihalik JL, MoormanEavers ER. Perceived similarity and relationship success among dating couples: an idiographic approach. Journal of Social and Personal Relationships. 2006; 23(6):865-80.

[12] Fine M, Harvey J. Predictors of divorce and relationship dissolution. Handbook of Divorce and Relationship Dissolution. 2004.

[13] More women opt for divorce despite risks. The Jakarta Post. 2016. http://www.thejakartapost.com/news/2016/08/24/more -women-opt-for-divorce-despite-risks.html. Accessed 27 September 2017.

[14] Myers DG, Twenge JM. Social psychology. McGrawHill; 2013.

[15] Duveen G, Lloyd B. Social representations and the development of knowledge. Cambridge University Press; 1990.

[16] Marchiori PZ, Appel AL, Bettoni EM, Tsunoda DF, Alcântara FC. Elements of social representation theory in collaborative tagging systems. TransInformação. 2014; 26(1):27-37.

[17] Wagner W, Duveen G, Farr R, Jovchelovitch S, Lorenzi-Cioldi F, Marková I, et al. Theory and method of social representations. Asian Journal of Social Psychology. 1999; 2(1):95-125.

[18] Breakwell GM. Social representations and social identity. Papers on Social Representations. 1993; 2(3):198-217.

[19] Gravetter FJ, Forzano LB. Research methods for the behavioral sciences. Wadsworth Publishing; 2011.

[20] Jordan A, Kunkel D, Manganello J, Fishbein M. Media messages and public health: a decisions approach to content analysis. Routledge; 2009.

[21] Williams B, Onsman A, Brown T. Exploratory factor analysis: a five-step guide for novices. Journal of Emergency Primary Health Care. 2010; 8(3):1-13.

[22] Santrock JW. Life-span development. McGraw-Hill Education. 2014.

[23] Neuman WL. Social research methods: qualitative and quantitative approaches. Allyn and Bacon; 2011.

[24] Alhojailan MI. Thematic analysis: a critical review of its process and evaluation. West East Journal of Social Sciences. 2012; 1(1):39-47.

[25] Tiggemann M, Zaccardo M. Strong is the new skinny: a content analysis of \# fitspiration images on instagram. Journal of Health Psychology. 2016.

[26] Hinkin TR, Tracey JB, Enz CA. Scale construction: developing reliable and valid measurement instruments. Journal of Hospitality \& Tourism Research. 1997; 21(1):100-20. 
[27] Ranta M, Dietrich J, Salmela-Aro K. Career and romantic relationship goals and concerns during emerging adulthood. Emerging Adulthood. 2014; 2(1):17-26.

[28] Abdullaha ZH, Ismaila S, Muradb AH. Awareness level towards the validity and reliability of electronic information among students. International conference on information technology \& society. 2015 (pp. 38794). Kuala Lumpur, Malaysia.

[29] Woychick L. Study abroad-'self'ie: US international student identity and cross-cultural adaptation on instagram. Doctoral Dissertation, Gonzaga University. 2016.

[30] Tavakol M, Dennick R. Making sense of Cronbach's alpha. International Journal of Medical Education. 2011; 2:53-5.

[31] Abraham J, Rahardjo W. Psychopathy, sexual values dimensions, and premarital sexual behaviour among urban unmarried adolescents. Procedia-Social and Behavioral Sciences. 2015; 165:2-11.

[32] Yong AG, Pearce S. A beginner's guide to factor analysis: focusing on exploratory factor analysis. Tutorials in Quantitative Methods for Psychology. 2013; 9(2):79-94.

[33] Fowers BJ, Laurenceau JP, Penfield RD, Cohen LM, Lang SF, Owenz MB, et al. Enhancing relationship quality measurement: the development of the relationship flourishing scale. Journal of Family Psychology. 2016; 30(8):997-1007.

[34] MacKenzie MJ, Baumeister RF. Meaning in life: nature, needs, and myths. In meaning in positive and existential psychology 2014 (pp. 25-37). Springer New York.

[35] Graham JM, Harf MR. Self-expansion and flow: the roles of challenge, skill, affect, and activation. Personal Relationships. 2015; 22(1):45-64.

[36] Deci EL, Ryan RM. The" what" and" why" of goal pursuits: human needs and the self-determination of behavior. Psychological Inquiry. 2000; 11(4):227-68.

[37] Sternberg RJ, Weis K. The new psychology of love. Yale University Press; 2006.

[38] Zimmer-Gembeck MJ, Arnhold V, Connolly J. Intercorrelations of intimacy and identity dating goals with relationship behaviors and satisfaction among young heterosexual couples. Social Sciences. 2014; 3(1):44-59.

[39] Ducat WH, Zimmer-Gembeck MJ. Romantic partner behaviours as social context: measuring six dimensions of relationships. Journal of Relationships Research. 2010; 1(1):1-16.

[40] Kelly M, Zimmer-Gembeck MJ, Boislard-P MA. Identity, intimacy, status and sex dating goals as correlates of goal-consistent behavior and satisfaction in Australian youth. Journal of Adolescence. 2012; 35(6):1441-54.

[41] Cooke A, Eipl K, Jacobs R. Religiosity and spirituality: effects on closeness in romantic relationships. 2012.
[42] Fard MK, Shahabi R, Zardkhaneh SA. Religiosity and marital satisfaction. Procedia-Social and Behavioral Sciences. 2013; 82:307-11.

[43] Istiqomah I, Mukhlis M. Hubungan antara religiusitas dengan kepuasan perkawinan. Jurnal Psikologi. 2015; 11(2):71-8.

[44] Mathur A, Barak B, Zhang Y, Lee KS, Yoo B, Ha J. Social religiosity: concept and measurement across divergent cultures. Asia Pacific Journal of Marketing and Logistics. 2015; 27(5):717-34.

[45] Li T, Fung HH. The dynamic goal theory of marital satisfaction. Review of General Psychology. 2011; 15(3):246-54.

[46] Muther C. The growing culture of impatience makes us crave more and more instant gratification. The Boston Globe. 2013.

[47] Oloo FL. "Instagratification": uses and gratification of instagram by university students for interpersonal communication. Doctoral Dissertation, Eastern Mediterranean University (EMU). 2013.

[48] Coontz S. The origins of modern divorce. Family Process. 2007; 46(1):7-16.

[49] Khazan O. We expect too much from our romantic partners. https://www.theatlantic.com/health/archive/2017/09/w e-expect-way-too-much-from-our-romanticpartners/541353/ Accessed 3 November 2017.

[50] Maslow AH. Motivation and personality. Pearson Education; 1987.

[51] Beck U, Beck-Gernsheim E. Losing the traditional: individualization and 'precarious freedoms'. Identity in Question. 2009:13-36.

[52] Krems JA, Kenrick DT, Neel R. Individual perceptions of self-actualization: what functional motives are linked to fulfilling one's full potential? Personality and Social Psychology Bulletin. 2017; 43(9):1337-52.

[53] Paxton AL, Turner EJ. Self-actualization and sexual permissiveness, satisfaction, prudishness, and drive among female undergraduates. Journal of Sex Research. 1978; 14(2):65-80.

[54] Hicks LL, McNulty JK, Meltzer AL, Olson MA. Capturing the interpersonal implications of evolved preferences? frequency of sex shapes automatic, but not explicit, partner evaluations. Psychological Science. 2016; 27(6):836-47.

[55] Smith A, Lyons A, Ferris J, Richters J, Pitts M, Shelley J, et al. Sexual and relationship satisfaction among heterosexual men and women: the importance of desired frequency of sex. Journal of Sex \& Marital Therapy. 2011; 37(2):104-15.

[56] Asyari S, Abid MH. Expanding the Indonesian tarbiyah movement through taaruf and marriage. AlJamiah: Journal of Islamic Studies. 2016; 54(2):33768.

[57] Juneman J, Rahardjo W. Influence of sexual values on perceived risk of interfaith marriage among unmarried urban students in Jakarta. Humaniora.2013; 25(1):313. 
Azizah et al.

[58] Lauer SR, Yodanis C. Individualized marriage and the integration of resources. Journal of Marriage and Family. 2011; 73(3):669-83.

[59] Yodanis C, Lauer S. Is marriage individualized? What couples actually do. Journal of Family Theory \& Review. 2014; 6(2):184-97.

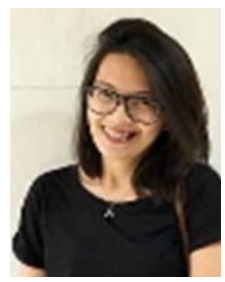

Afifah Azizah is a junior researcher in Social/Community Psychology concentration at Psychology Department, Faculty of Humanities, Bina Nusantara University. She has just completed her thesis and is waiting for receiving Bachelor of Psychology from Bina Nusantara University.

Email: afiiazii@gmail.com

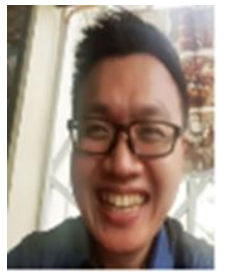

Juneman Abraham is a social psychologist who put interest on psychoinformatics. Currently, he is a Senior Faculty Member-Subject Content Coordinator of Community Psychology Studies at Bina Nusantara University; Head of Organizational Compartment, National Office of Indonesian Psychological Association; Certified Webmaster Professional of WOW Academy; Secretary of the Editorial Board of Indonesian Psychological Journal; Member of Indonesian Association of Social Psychology, Asian Association of Social Psychology, and World Association of Personality Psychology.

Email: juneman@binus.ac.id 